\begin{tabular}{lllllllllllllllll}
$\mathrm{S}$ & $\mathrm{T}$ & $\mathrm{U}$ & $\mathrm{D}$ & $\mathrm{I}$ & $\mathrm{A}$ & & $\mathrm{T}$ & $\mathrm{E}$ & $\mathrm{M}$ & $\mathrm{A}$ & $\mathrm{T}$ & $\mathrm{Y}$ & $\mathrm{C}$ & $\mathrm{Z}$ & $\mathrm{N}$ & $\mathrm{E}$ \\
\hline
\end{tabular}

STUDIA Z PRAWA WYZNANIOWEGO

Tom $21-2018$

DOI: https://doi.org/10.31743/spw.197

MARIUSZ GRABOWSKI*

\title{
PRAWNE ASPEKTY DZIAŁALNOŚCI PUBLICZNEJ DUCHOWNYCH
}

\author{
Streszczenie
}

W polskim systemie prawnym pojęcie „duchownego" jest ustalane na podstawie wewnętrznych regulacji kościołów i innych związków wyznaniowych. Duchowni, będący obywatelami polskimi, mają identyczne prawa jak wszyscy inni obywatele. Ograniczenie praw duchownych w przedmiotowym zakresie, byłoby złamaniem konstytucyjnych zasad, postanowień ratyfikowanych umów międzynarodowych oraz przepisów ustawowych.

Kodeks Prawa Kanonicznego Kościoła Katolickiego zawiera bezwzględny zakaz sprawowania przez duchownych publicznych urzędów, z którymi łączy się udział w wykonywaniu władzy świeckiej (kan. 285 §3 KPK), zakaz takiego uczestnictwa w stowarzyszeniach, które pozostają w kolizji z obowiązkami duchownych (kan. 278 §3 KPK) oraz względny zakaz czynnego udziału w partiach politycznych albo w kierowaniu związkami zawodowymi (kan. 287 §2 KPK). Wszelkie ograniczenia dotyczące działalności publicznej duchownych można rozpatrywać wyłącznie na gruncie prawa kanonicznego. Wynika to z obowiązującego porządku prawnego, w tym z konstytucyjnej zasady autonomii Kościoła i państwa.

Słowa kluczowe: duchowni; kościoły i inne związki wyznaniowe; wolność religijna; Kościół Katolicki; autonomia Kościoła i państwa; funkcje publiczne; prawa konstytucyjne

\section{$* * * * *$}

* Dr, Katedra Prawa Polskiego i Międzynarodowego, Wydział Prawa Kanonicznego, Uniwersytet Kardynała Stefana Wyszyńskiego w Warszawie, ul. Dewajtis 5, 01-815 Warszawa, e-mail: margrab5@o2.pl. ORCID 0000-0003-3783-6867. 


\section{UWAGI WSTĘPNE}

Przedmiotem opracowania są wybrane prawne aspekty działalności publicznej duchownych. Zamieszczone poniżej uwagi formułowane są na gruncie prawa państwowego ${ }^{1}$, przy czym niezbędne jest także odniesienie do norm prawa kanonicznego w zakresie wyznaczonym przedmiotem artykułu. Istota konkluzji oraz charakter przyjmowanych stanowisk zakorzenione są w pierwszym z wymienionych porządków prawnych. Niniejszy artykuł jest próbą odpowiedzi na głosy wyrażane z pozycji prawodawstwa państwowego oraz te, które są formułowane na tle relacji prawa państwowego i prawa kanonicznego. W drugim przypadku chodzi o tezy stawiane przez każdą ze stron tej relacji. Rozważania dotyczą duchownych Kościoła Rzymskokatolickiego, jednakże istota zawartych poniżej uwag jest aktualna także w odniesieniu do innych wyznań, oczywiście oprócz kwestii związanych wyłącznie z porządkiem prawa kanonicznego Kościoła Rzymskokatolickiego. Przyjęte w niniejszym opracowaniu pojęcie „działalności publicznej” oznacza publiczną aktywność, w najszerszym tego słowa znaczeniu. Działalnością publiczną jest więc tutaj aktywność w sferze publicznej, rozumianej jako nieprywatnej (osobistej), która to aktywność jest związana ze sprawowaniem posługi osoby duchownej. Przykładowo, będą to upublicznione wypowiedzi osoby duchownej, które są realizacją zadań właściwych tej osobie jako duchownej. Wyłączając kwestię statusu osoby duchownej na tle wewnętrznego prawa kościelnego, przedmiot rozważań wraz z konkluzjami - jest aktualny także w odniesieniu do osoby duchownej, jako obywatela państwa. W ramach „działalności publicznej” zawiera się także pojęcie takiej działalności, która jest publiczną w rozumieniu prawa państwowego. W tym węższym znaczeniu mamy do czynienia $\mathrm{z}$ „osobą publiczną”, czy też „funkcjonariuszem publicznym”.

Problematyka szeroko rozumianej działalności publicznej osób duchownych, w tym sprawowania przez nie funkcji publicznych, jest przedmiotem ożywionych dyskusji w państwach współczesnej demokracji, w tym również w Polsce. Przedmiotem spornych wypowiedzi są działania osób duchownych, które są podejmowane w związku z pełnieniem funkcji duchownego oraz takie, które wprawdzie nie mają bezpośredniego związ-

1 Prawa polskiego oraz prawa międzynarodowego. 
ku z posługą duchowną ${ }^{2}$ jednak są w powyższej dyskusji identyfikowane $\mathrm{z}$ taką posługą z racji na tożsamość osób oraz przenikanie się ról, w jakich te osoby występują. Warto poświęcić uwagę co najmniej wyjaśnieniu różnych nieporozumień, w szczególności zaś potrzebna jest jednoznaczna odpowiedź na kwestię, która jest istotą publicznych sporów, a która ma pierwszorzędne znaczenie - o aksjologiczno-ustrojowym charakterze - w państwie. Jest nią zagadnienie statusu prawnego osoby duchownej w państwie oraz związane $\mathrm{z}$ tym pytania o podstawę i zakres ewentualnego różnicowania tego statusu, w porównaniu ze ,zwykłym” obywatelem. Znamienne jest to, że krytyka podnoszona w interesującej nas mierze jest - co do zasady - lokowana w obszarze prawa państwowego. Wieloaspektowość poruszanego tematu sprawia, że wyczerpujące jego omówienie wymagałoby obszernej monografii, toteż nie są przedmiotem rozważań szczegółowe kwestie związane z pełnieniem konkretnej funkcji publicznej ${ }^{3}$. Nie ma także miejsca na wyczerpujące rozpatrzenie problematyki wolności słowa (wypowiedzi), należącej wprawdzie do istoty wspomnianego sporu, lecz będącej fragmentem zagadnienia. Jak wyżej wskazano, opracowanie sprowadza się do ,zbiorczej" problematyki obywatelskich praw osób duchownych. Poruszam więc wybrane, ważniejsze aspekty prawne działalności publicznej duchownych, dobrane w odniesieniu do postawionego wyżej pytania o status prawny takiej osoby. Należą do nich: sprawowanie publicznych urzędów, działalność w partiach politycznych, związkach zawodowych i innych organizacjach o charakterze społeczno-politycznym, aktywność medialna, zagadnienie praw z zakresu tzw. obywatelskich praw politycznych. Przybliżenie rozwiązań właściwych dla porządków prawa państwowego i kościelnego służy nie tylko celom opisowym ${ }^{4}$, ale przede wszystkim uzasadnieniu wniosków.

\section{POJĘCIE „OSOBY DUCHOWNEJ” I „DZIAŁALNOŚCI PUBLICZNEJ”}

Sprecyzowania wymaga pojęcie „osoby duchownej”. W polskim prawodawstwie nie ma legalnej definicji „duchownego”, zarówno jeśli chodzi

\footnotetext{
2 Są właściwe dla danej osoby jako „zwykłego” obywatela państwa.

3 W rozumieniu prawa państwowego, np. w obszarze wojskowości.

4 Co samo w sobie byłoby pożyteczne dla wielu uczestników publicznych dyskusji.
} 
o definicję ustawową, jak i o dookreślenie tego pojęcia w aktach prawnych niższego rzędu. Jednakże polski prawodawca posługuje się tym terminem. Dla przykładu przytoczyć można przepisy: 1) art. 24 ustawy z dnia 17 maja 1989 r. o stosunku Państwa do Kościoła Katolickiego w Rzeczypospolitej Polskiej ${ }^{5}$, zgodnie z którym, że „osoby duchowne i członkowie zakonów” mają prawo do kształcenia się w szkołach państwowych ${ }^{6}$; inne przepisy tej ustawy używają wyrażenia „duchowni” w różnych odmianach ${ }^{7} ; 2$ ) art. 12 ustawy z dnia 17 maja 1989 roku o gwarancjach wolności sumienia i wyznania ${ }^{8}$ posługuje się wyrażeniami „duchowni”" i „osoba zakonna”; 3) szereg przepisów dotyczących sytuacji prawnej duchownych zamieszczonych np. w art. 82 pkt 3 Kodeksu postępowania administracyjnego ${ }^{10}$; w art. $261 \S 2$ Kodeksu postępowania cywilnego ${ }^{11}$; w art. 178 pkt 2 Kodeksu postępowania karnego ${ }^{12}$; w art. $1 \S 2$ Kodeksu rodzinnego i opiekuńczego ${ }^{13}$; w art. 33 pkt 3 lit. c ustawy z dnia 28 listopada 2014 r. prawo o aktach stanu cywilnego ${ }^{14}$; w art. 43 pkt 2 ustawy z dnia 23 grudnia 1994 r. o Najwyższej Izbie Kontroli ${ }^{15}$; w art. 195 pkt 3 ustawy z dnia 29 sierpnia 1997 r. ordynacja podatkowa ${ }^{16}$; w art. 4 pkt 2 lit. $\mathrm{f}^{17}$ ustawy z dnia 13 października 1998 r. o sy-

5 Tekst jedn. Dz. U. z 2018 r., poz. 380.

${ }^{6}$ Tym samym terminem posługuje się art. 29 ust. 2 i art. 55 ust. 5 oraz art. 57 ust. 1 tej ustawy.

Art. 15a ust.2; art. 29 ust. 2, 3 i 4; art. 55 ust. 5; art. 57 ust. 1; art. 69; art. 71 ust.1 i 2.

8 Tekst jedn. Dz. U. z 2017 r., poz. 1153.

9 Także art. 19 ust. 2 pkt 5; art. 32 ust. 2 pkt 9 tej ustawy.

10 Ustawa z dnia 14 czerwca 1960 r. Kodeks postępowania administracyjnego, tekst jedn. Dz. U. z 2018 r., poz. 2096.

11 Ustawa z dnia 17 listopada 1964 r. Kodeks postępowania cywilnego, tekst jedn. Dz. U. z 2018 r., poz. 1360.

12 Ustawa z dnia 6 czerwca 1997 r. Kodeks postępowania karnego, tekst jedn. Dz. U. z 2018 r., poz. 1987.

13 Ustawa z dnia 25 lutego 1964 r. Kodeks rodzinny i opiekuńczy, tekst jedn. Dz. U. z 2017 r., poz. 682. Także art. 8; art. 9 §2 tej ustawy.

14 Tekst jedn. Dz. U. z 2016 r., poz. 2064 z późn. zm. Także art. 81 ust. 3; art. 82 ust. 1; art. 86 ust. 3 ; art. 87 ust. 3 i 4 tej ustawy.

15 Tekst jedn. Dz. U. z 2017 r., poz. 524.

16 Tekst jedn. Dz. U. z 2018 r., poz. 800 z późn. zm.

17 Także art. 6 ust. 1 pkt 10; art. 6 a ust. 1 pkt 5; art. 9 ust. 7; art. 13 pkt 10; art. 14 ust. 2 pkt 2; art. 16 ust. 10, 10a, 11; art. 18 ust. 4 pkt 5a, ust. 4c, ust. 11; art. 36 ust. 2; art. 47 ust. 2d; art. 122 pkt 6 tej ustawy. 
stemie ubezpieczeń społecznych ${ }^{18}$. Przepis art. 8 ust. 13 tej ostatniej ustawy, definiując na jej użytek pojęcie „osoby duchownej”, odsyła - co znamienne - do pojęć „duchownego” i „członka zakonu” w rozumieniu wewnętrznych regulacji „Kościoła Katolickiego [oraz] innych kościołów i związków wyznaniowych". Ponadto wskazać jeszcze należy art. 13 pkt 3 ustawy z dnia 26 lipca 1991 r. o podatku dochodowym od osób fizycznych ${ }^{19}$ i art. 1 pkt 3 ustawy z dnia 20 listopada 1998 r. o zryczałtowanym podatku dochodowym od niektórych przychodów osiąganych przez osoby fizyczne ${ }^{20}$. Przepis art. 2 ust. 2 tej ustawy odsyła do terminu „osób duchownych” w znaczeniu przyjętym w wewnętrznych regulacjach ,prawnie uznanych wyznań”.

Reasumując, w polskim systemie prawnym znaczenie pojęcia „duchownego" jest ustalane na podstawie wewnętrznych regulacji Kościoła (kościołów i innych związków wyznaniowych). W doktrynie podkreśla się ten fakt, jako zasadę wyrażoną przez samego prawodawcę w ustawowych przepisach regulujących sytuację prawną Kościoła i innych związków wyznaniowych w Polsce oraz stosunek państwa do nich ${ }^{21}$. Wyjątkiem od powyższej zasady nie jest sytuacja, gdy sam prawodawca „określa” kto jest duchownym uprawnionym w zakresie przyjmowania oświadczeń o zawarciu małżeństwa, jak to ma miejsce w przepisie art. 91 ustawy z dnia 28 listopada 2014 r. prawo o aktach stanu cywilnego. Zgodnie z tym przepisem, „minister właściwy do spraw wewnętrznych na podstawie informacji otrzymanych od właściwych przedstawicieli kościołów i innych związków wyznaniowych obwieszcza w Dzienniku Urzędowym Rzeczypospolitej Polskiej „Monitor Polski” wykaz stanowisk, których zajmowanie upoważnia do przyjmowania oświadczeń o wstąpieniu w związek małżeński oraz sporządzania zaświadczeń stanowiących podstawę sporządzania aktu małżeństwa zawartego w sposób określony w art. 1 \$2 i 3 Kodeksu rodzinnego i opiekuńczego". Cytowany przepis także odsyła nas do wewnętrznych regulacji kościołów i związków wyznaniowych, toteż nie ma tu żadnego elementu ,władczego" po stronie państwa. Odstępstwo od powyższej zasa-

18 Tekst jedn. Dz. U. z 2017 r., poz. 1778.

19 Tekst jedn. Dz. U. z 2018 r., poz. 1509 z późn. zm. Także art. 24a ust. 2 pkt 3; art. 13 pkt 3 tej ustawy.

20 Tekst jedn. Dz. U. z 2017 r., poz. 2157 z późn. zm. Także przepisy rozdziału 4 tej ustawy pt. „Zryczałtowany podatek dochodowy od przychodów osób duchownych”.

21 Por. Tunia 2014, 68; Mezglewski 2001, 3-26; Mezglewski 2005, 193-206. 
dy byłoby zresztą naruszeniem konstytucyjnych zasad wolności religijnej (sumienia i wyznania) oraz autonomii kościoła i państwa. Ponadto - w odniesieniu do Kościoła Rzymskokatolickiego - byłoby to w sprzeczności z postanowieniami Konkordatu ${ }^{22}$, które mają pierwszeństwo przed przepisami ustawowymi ${ }^{23}$. Pojęcie ,duchownego" nie jest przedmiotem międzynarodowych regulacji prawnych z zakresu prawa „niekościelnego”, których Polska jest stroną.

W nawiązaniu do wyrażonego wyżej celu niniejszego opracowania wypada zauważyć, że powyższe znaczenie pojęcia „duchownego” jest tożsame ze znaczeniem używanym powszechnie w naszym państwie w publicznych dyskusjach.

Pojęcie „działalność publiczna” jest tradycyjnie przypisywane aktywności związanej z funkcją, która jest przedmiotem regulacji przede wszystkim prawa publicznego, np. dotyczących określonego funkcjonariusza państwowego, co jednocześnie wyznacza definicję „osoby publicznej”. Jest rzeczą słuszną przypisywanie takiego znaczenia, jeśli chodzi o pierwszeństwo terminologicznego sformułowania. Zakres przymiotnika „publiczny” jest w praktyce stosowania prawa ${ }^{24}$ rozszerzany na gruncie prawa prywatnego, np. prawa własności intelektualnej, gdzie funkcjonuje szersze określenie „osoby publicznej” wyznaczające zarazem znaczenie „działalności publicznej”. Za „osobę publiczną” uważa się nie tylko piastującą urząd państwowy (publiczny), ale też taką, która z racji na swoją działalność jest „powszechnie” znana. Sama zaś „działalność” oznacza określoną profesję, z racji na którą osoba jest powszechnie znana. Chodzi tu więc o takie zajęcie (np. zawód), które ze swej istoty „upublicznia” osobę, np. aktora filmowego, prezentera telewizyjnego, znanego działacza społecznego, sportowca olimpijskiego. Oczywiście, takie znaczenie „osoby publicznej” i „działalności publicznej”, które wyznaczone jest nieprecyzyjnym kryterium ,bycia powszechnie znanym”, jest daleko szersze w porównaniu do poprzedniego. Samo zaś pojęcie ,,powszechnie znany”

22 Konkordat między Stolicą Apostolską i Rzecząpospolitą Polską podpisany dnia 28 lipca 1993 r., Dz. U. z 1998 r. Nr 51, poz. 318. Por. Dudziak 2002.

23 Na mocy art. 91 ust. 2 Konstytucji RP (Dz. U. z 1997 r. Nr 78, poz. 483). W sprawie skutków prawnych ratyfikacji Konkordatu por. Krukowski 2008, 96-105.

24 Np. na tle art. 81 ust. 2 pkt 1 ustawy z dnia 4 lutego 1994 r. o prawie autorskim i prawach pokrewnych, tekst jedn. Dz. U. z 2018 r., poz. 1191 z późn. zm. 
używane jest ${ }^{25} \mathrm{w}$ kontekście kryterium obszaru, na którym dana osoba jest znana. Toteż osoba duchowna byłaby w tym wypadku ,powszechnie” znana w wymiarze lokalnym - np. proboszcz parafii, albo też ogólnopolskim, z racji na inną funkcję albo rodzaj zaangażowań. W dyskusji publicznej (upowszechnionej), kryterium obszaru, używane w argumentacji polityczno-propagandowej, jest wyjątkowo płynne. Przykładem może być „parafialne" kazanie do wiernych, które po nagłośnieniu przez ogólnokrajowe media, staje się przedmiotem „publicznej”, tzn. powszechnej dyskusji, a sama osoba duchowna staje się po nagłośnieniu powszechnie znaną. Nie można nie dostrzegać tej rzeczywistości i ograniczać rozważań wyłącznie do „działalności publicznej” w znaczeniu wąskim. To ostatnie zdanie podyktowane jest zakreślonym we wstępie zakresem rozważań, bez ujmy dla słuszności badań nad kwestią ,publiczności” osób duchownych w wąskim rozumieniu, w tym nad konkretnymi zagadnieniami szczegółowymi.

\section{PRAWNE ASPEKTY DZIAŁALNOŚCI PUBLICZNEJ DUCHOWNYCH}

\subsection{UWAGI NA GRUNCIE PAŃSTWOWEJ REGLAMENTACJI PRAWNEJ}

Charakterystycznym punktem wyjścia dla krytykujących ${ }^{26}$ fakt udziału osób duchownych w życiu publicznym, jak i dla tych, którzy próbują wyznaczyć dopuszczalne ramy tego udziału, jest bezpodstawne i irracjonalne założenie o rzekomej ,inności” duchownych jako obywateli państwa w ogóle, z czego wyprowadzany jest swoisty zakres przysługujących im praw obywatelskich. Jest oczywiste, że duchowni będący obywatelami polskimi, cieszą się - na gruncie prawa państwowego - identycznymi prawami, jak wszyscy inni obywatele. Ponadto, kwestionowanie praw duchownych - w omawianym aspekcie - jest jednocześnie naruszeniem praw konstytucyjnych wszystkich ,pozostałych” obywateli państwa polskiego, w szczególności zaś wiernych ${ }^{27}$. Próba jakiegokolwiek ograni-

25 W procesie stosowania prawa.

26 Krytykujących z pozycji prawodawstwa „niekościelnego”.

27 Którzy też mają prawo do obecności duchownych w przestrzeni publicznej. Ponadto, aksjologiczna istota negacji lub ograniczania działalności publicznej duchownych, wyrażana przez osoby nieprzychylne Kościołowi, sprowadza się do postulatu wykluczenia z życia publicznego wszelkich treści, zachowań i postaw zawierających pierwiastek reli- 
czenia praw duchownych w przedmiotowym zakresie byłaby złamaniem konstytucyjnych zasad, zbieżnych $\mathrm{z}$ nimi postanowień ratyfikowanych umów międzynarodowych oraz przepisów ustawowych uszczegóławiających konstytucyjne zasady. Katalog tych naruszeń można zacząć od faktu pogwałcenia zasady autonomii Kościoła i państwa, która najczęściej bywa punktem wyjścia dla prowadzących krytykę. Dalej, poprzez konstytucyjne (i traktatowe) zasady wolności religijnej ${ }^{28}$ (sumienia, wyznania, religii), na konstytucyjnym katalogu praw i wolności obywatelskich kończąc.

Polski prawodawca wyraźnie wskazał - znamiennym, aczkolwiek oczywistym w świetle porządku konstytucyjnego - postanowieniem art. 1 ust. 3 ustawy o gwarancjach wolności sumienia i wyznania, że „obywatele wierzący wszystkich wyznań oraz niewierzący mają równe prawa w życiu państwowym, politycznym, gospodarczym, społecznym i kulturalnym”. Ponadto w art. 12 ust. 1 tej ustawy stanowi, że ,duchowni oraz osoby zakonne kościołów i innych związków wyznaniowych, ustanowione według przepisów prawa wewnętrznego kościoła lub innego związku wyznaniowego, korzystają z praw (...) na równi z innymi obywatelami we wszystkich dziedzinach życia państwowego, politycznego, gospodarczego, społecznego i kulturalnego".

Nie można oczywiście nie zauważyć uwarunkowań i konsekwencji bycia osobą duchowną, w tym faktu powszechnego utożsamiania takiej osoby - i jej aktywności - z autorytetem i misją własnego stanu oraz samego Kościoła. Stąd też, zgodnie z zasadą autonomii Kościoła i państwa, rola prawodawcy kościelnego, a nie państwowego, w określeniu właściwych ram w tym zakresie. Z taką sytuacją mamy do czynienia na gruncie prawo-

gijny. Dyskryminacja dotyczy więc wszystkich wierzących, niezależnie od ich statusu we wspólnocie Kościoła.

${ }_{28}$ Za właściwe należy uznać określenie ,wolność religijna”, którego zamienniki nazewnicze, takie jak ,wolność sumienia”, ,wolność wyznania”, ,wolność religii” są nieadekwatne zarówno ze względu na semantyczne, jak i przedmiotowe znaczenie. Tak np. Bielecki 2014b, 513-520. Zwłaszcza w odniesieniu do „wolności sumienia”, które językowo sugeruje redukcję wolności religijnej do aspektu prywatności, a przecież - jak wskazuje M. Bielecki - „wolność uzewnętrzniania przekonań religijnych jest wyrazem i gwarantem korzystania z wolności religijnej”, Bielecki 2014a, 495. Por. m.in. Abramowicz 2007, 325352; Misztal 1993, 103-122. 
dawstwa Kościoła Rzymskokatolickiego, od Kodeksu Prawa Kanonicznego $^{29}$ zaczynając, o czym poniżej.

Odmienne traktowanie prawnej pozycji duchownego byłoby sprzeczne z normami prawa międzynarodowego wiążącymi Polskę oraz z prawodawstwem wewnętrznym.

Istotne, w przedmiocie rozważań, akty prawa międzynarodowego ${ }^{30}$ jednoznacznie wyrażają prawo do wolności religijnej oraz zakaz dyskryminacji ze względu na kryterium religii. Normy te, jako dotyczące wszystkich bez wyjątku, obejmują rzecz jasna także duchownych. Truizm ten jest przytaczany w tym miejscu dlatego, że zwolennicy ograniczania praw duchownych w zakresie działalności publicznej, nie dostrzegają tego faktu.

Warto podkreślić, że powyższe normy odwołują się do prawnonaturalnego źródła i podstawy obowiązywania praw człowieka (obywatela), poprzez odwołanie się do ,przyrodzonej godności człowieka”. Prawo do wolności religijnej i będący wyrazem tego prawa zakaz dyskryminacji, nie mając swojego jedynego i ostatecznego źródła w prawie państwowym, lecz w prawie naturalnym, winny być zabezpieczone prawem stanowionym. Należy to do podstawowych obowiązków prawodawcy. Na ewentualny zarzut ${ }^{31}$ o prawnonaturalność podstaw niniejszej wypowiedzi wypada przypomnieć, że odpowiedź została już udzielona w dramatycznym powrocie do prawa naturalnego przez międzynarodową społeczność w czasie Trybunału w Norymberdze, czego rezultatem była m.in. Powszechna Deklaracja Praw Człowieka.

Należy odwołać się do aktów prawa międzynarodowego, których Polska jest stroną, a które zawierają katalogi praw człowieka (obywatela). Omawianie wszystkich tych praw $^{32}$ wykracza poza ramy niniejszej wypowiedzi, której przedmiotem jest poszukiwanie prawnych podstaw różnicowania sytuacji prawnej duchownych w ich działalności publicznej

29 Codex Iuris Canonici auctoritate Ioannis Pauli PP. II promulgatus (25.01.1983), AAS 75 (1983), cz. II, s. 1-317; tekst polski: Kodeks Prawa Kanonicznego. Przekład polski zatwierdzony przez Konferencję Episkopatu Polski, Poznań: Pallotinum 1984. Dalej: KPK.

30 Którego normy mają zastosowanie w polskim prawie, przy zachowaniu pierwszeństwa przed przepisami ustawowymi.

31 Kontestacja praw osób duchownych jest prowadzona głównie z pozycji pozytywizmu prawnego, jako uaspektowiona próba redukcji wolności religijnej.

32 Np. wolności dotyczącej związków zawodowych, itd. 
w porównaniu z ,pozostałymi” obywatelami. Cytowane regulacje prawa międzynarodowego nie przewidują takiego różnicowania w odniesieniu do któregokolwiek z poruszanych praw, toteż zasadniczo wystarcza przywołanie: po pierwsze, przepisów wyrażających jedno ze skatalogowanych praw, jakim jest wolność religijna oraz, po drugie, przepisów zawierających zakaz dyskryminacji ze względu na kryterium religii (wyznania).

Do takich przepisów należą: 1) art. 1 i art. 18 Powszechnej Deklaracji Praw Człowieka uchwalonej przez Zgromadzenie Ogólne Organizacji Narodów Zjednoczonych w 1948 r. ${ }^{33}$, zgodnie z którymi, odpowiednio: „wszyscy ludzie rodzą się wolni i równi w swej godności i w swych prawach (...), a „każdy człowiek ma prawo do wolności myśli, sumienia i religii (...)”. Deklaracja zawiera zakaz dyskryminacji z racji na religię zgodnie z art. 2 ,każdy człowiek jest uprawniony do korzystania z wszystkich praw i wolności (...) bez względu na różnice (..) religii (...) lub jakiekolwiek inne różnice”, a art. 7 stanowi, że wszyscy są równi wobec prawa i mają prawo do jednakowej ochrony przed jakąkolwiek dyskryminacją. Deklaracja dopuszcza możliwość prawnego ograniczenia praw i wolności, ale „wyłącznie w celu zapewnienia odpowiedniego uznania i poszanowania praw i wolności innych oraz w celu uczynienia zadość słusznym wymogom moralności, porządku publicznego i powszechnego dobrobytu demokratycznego społeczeństwa" (art. 29 ust. 2). Jednocześnie ,żadnego z postanowień niniejszej Deklaracji nie można rozumieć jako udzielającego jakiemukolwiek Państwu, grupie lub osobie jakiegokolwiek prawa do podejmowania działalności lub wydawania aktów zmierzających do obalenia któregokolwiek z praw i wolności proklamowanych w niniejszej Deklaracji” (art. 30). Wagę równości wobec prawa, w omawianym zakresie, podkreślają przepisy zawarte w Deklaracji z dnia 25 listopada 1981 r. w sprawie wyeliminowania wszelkich form nietolerancji i dyskryminacji opartych na religii lub przekonaniach ${ }^{34}$.

2) Do wspomnianych przepisów należy art. 18 ust. 1 Międzynarodowego Paktu Praw Obywatelskich i Politycznych, otwartego do podpisania

33 Rzeczpospolita Polska, jako członek ONZ, zobowiązała się do stosowania Deklaracji. Cyt. za oficjalnym tekstem UNESCO, http://www.unesco.pl/fileadmin/user_upload/pdf/ Powszechna_Deklaracja_Praw_Czlowieka.pdf [dostęp: 1.08.2017].

34 Por. na ten temat Stanisz, w: Mezglewski, Misztal, Stanisz 2011, 67. 
w Nowym Jorku dnia 19 grudnia 1966 r. ${ }^{35}$, który stanowi, że „każdy człowiek ma prawo do wolności myśli, sumienia i wyznania. W art. 2 ust. 1 zawarty jest zakaz dyskryminacji, min. ze względu na religię. Art. 26, stanowiąc że „wszyscy są równi wobec prawa”, zawiera jednocześnie zakaz dyskryminacji m.in. ze względu na religię. Art. 25 uszczegóławia, że „każdy obywatel ma prawo i możliwość, bez żadnej dyskryminacji” do uczestniczenia w życiu publicznym, w szerokim tych słów znaczeniu.

3) Do przywoływanych przepisów zaliczyć należy art. 9 Konwencji o ochronie praw człowieka i podstawowych wolności sporządzonej w Rzymie dnia 4 listopada 1950 r. (zmienionej Protokołami nr 3, 5, 8, 14 oraz uzupełnionej Protokołem nr 2) ${ }^{36}$, w którym czytamy - „Każdy ma prawo do wolności myśli, sumienia i wyznania (...)", które może być ograniczone wyłącznie na zasadach takich samych jak wyżej wymienione w pk.1). W art. 14 Konwencji zawarty jest zakaz dyskryminacji ze względu na religię.

4) Z kolei Traktat o Unii Europejskiej (art. 5) ${ }^{37}$ oraz Traktat o Funkcjonowaniu Unii Europejskiej (art. 17) ${ }^{38}$ zawierają zasadę nieingerencji w sprawy z zakresu stosunku do religii, które to sprawy są pozostawione wyłącznej kompetencji państw członkowskich (art. 5, 17) ${ }^{39}$. Zgodnie $\mathrm{z}$ art. 6 ust. 2 pierwszego z wymienionych Traktatów, UE przystępuje do europejskiej Konwencji z 1950 r. Z kolei Karta Praw Podstawowych ${ }^{40}$ powtarza zasadę równości wobec prawa i zakaz dyskryminacji ze względów

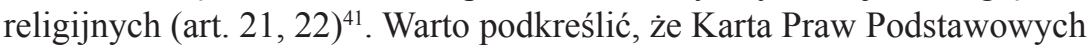
„ma taką samą moc prawną, jak Traktaty”"42 (art. 6 ust. 1 Traktatu o Unii Europejskiej). W interesującym nas zakresie, zgodnie z załączoną do Karty Deklaracja nr 61 Rzeczypospolitej Polskiej w sprawie Karty Praw Pod-

35 Dz. U. z 1977 r. Nr 38, poz. 167.

36 Dz. U. z 1993 r. Nr 61, poz. 284 (tekst pierwotny).

37 Dz. Urz. C 83 z 2010 r., s. 13.

38 Dz. Urz. C 83 z 2010 r., s. 47.

39 Por. Stanisz, w: Mezglewski, Misztal, Stanisz 2011, 42; Krukowski 2003, 217-230; Warchałowski 2004, 5-18.

40 Dz. Urz. C 303 z 2007 r., s. 1.

41 Por. Stanisz, w: Mezglewski, Misztal, Stanisz 2011, 34-47; Orzeszyna 2002, 175-195.

42 Chodzi o wspomniane już: Traktat o Unii Europejskiej i Traktat o Funkcjonowaniu Unii Europejskiej. 
stawowych Unii Europejskiej, „Karta w żaden sposób nie narusza prawa Państw Członkowskich do stanowienia prawa w zakresie (...) ochrony godności ludzkiej (...)".

Polska Konstytucja również odwołuje się do prawnonaturalnego źródła praw człowieka - przepis art. 30 stanowi, że „przyrodzona i niezbywalna godność człowieka stanowi źródło wolności i praw człowieka i obywatela". Art. 32 wyraża zasadę równości wszystkich wobec prawa oraz zakaz dyskryminacji kogokolwiek „w życiu politycznym, społecznym lub gospodarczym z jakiejkolwiek przyczyny". Zgodnie z art. 53 ust. 1, „każdemu zapewnia się wolność religii”. Konstytucja przewiduje możliwość ograniczenia praw konstytucyjnych, na wzór przytoczonych wyżej regulacji prawa międzynarodowego. Ograniczenia te są dopuszczalne, zgodnie z art. 31 ust. 3 Konstytucji, wyłącznie przy łącznym zachowaniu warunków: 1) ustawowego trybu wprowadzenia ograniczenia - w tym dopuszczalności ograniczeń wyłącznie w drodze ustawowej; 2) konieczności ograniczenia, tzn. jego niezbędności dla osiągnięcia uprawnionego celu; 3) uprawnionego celu ograniczenia, którym może być wyłącznie: bezpieczeństwo państwa, porządek publiczny, ochrona środowiska, ochrona zdrowia, ochrona moralności publicznej oraz wolności i prawa innych osób; 4) proporcjonalności ograniczenia, czyli właściwej relacji pomiędzy dobrem poświęcanym a dobrem zamierzonym.

Bliższe omówienie zagadnienia dopuszczalności powyższych ograniczeń wykracza poza przedmiot niniejszej wypowiedzi. Nasuwa się w tym miejscu pytanie o samą przedmiotowość, czy raczej bezprzedmiotowość tych ograniczeń, jeśli chodzi o wolność religijną w ogóle, a szczególnie w odniesieniu do tego wymiaru działalności publicznej duchownych, która polega na misji religijnej - czy istnieje sprzeczność pomiędzy ewangelizacją a którymkolwiek z dóbr wymienionych w art. 31 ust. 3 Konstytucji? Pytanie to wyznacza zarazem zakres problematyki w odniesieniu do przedmiotu niniejszego opracowania - czyż przedmiot i racja wskazanych ograniczeń nie istnieje wyłącznie na płaszczyźnie praw obywatelskich, w ,świeckim” ich znaczeniu, wymiarze i skonkretyzowaniu w określonych działaniach? Anachronicznie i niepokojąco brzmi zapis art. 53 ust. 5 Konstytucji, który powtarza, akurat w odniesieniu do wolności uzewnętrzniania religii, możliwość ograniczenia tej wolności dla „ochrony bezpieczeństwa państwa, porządku publicznego, zdrowia, moralności lub wolno- 
ści i praw innych osób". Czyż Ewangelia może zagrażać bezpieczeństwu państwa albo dobru drugiego człowieka? ${ }^{43}$ Słusznie podnoszony jest m.in. zarzut w odniesieniu do celu, jakim jest bezpieczeństwo państwa. Konflikt pomiędzy interesem państwa a dobrem człowieka jest pojęciem z zakresu systemów totalitarnych, a samo stawianie interesu państwa ponad dobro człowieka jest reliktem totalitaryzmu ${ }^{44}$.

Równość obywateli wobec prawa, niezależnie od religii, podkreśla polski prawodawca w przytoczonym już wyżej art. 1 ust. 3 ustawy o gwarancjach wolności sumienia i wyznania. $Z$ przepisu tego wynika, a contrario, zakaz dyskryminacji z przyczyn religijnych. Co więcej, równość ta jest podkreślona expressis verbis w odniesieniu do osób duchownych, którym przysługują prawa ,na równi z innymi obywatelami we wszystkich dziedzinach życia państwowego, politycznego, gospodarczego, społecznego i kulturalnego" (art. 12. ust. 3 tej ustawy).

Warto w tym miejscu zaznaczyć, że krytyka bądź negacja udziału duchownych w życiu publicznym, jest nie tylko bezprzedmiotowa w swej istocie, z prawnego punktu widzenia, ale i oparta na argumentacji contra legem. Jest przede wszystkim - w swym aksjomatycznym podłożu - konsekwencją błędnej interpretacji takich istotnych pojęć, jak samo „prawo” i ,polityka”, a w rezultacie ,,autonomii kościoła i państwa”, ,państwa prawa”, „wolności religijnej” itd. Niezgodne z obowiązującym prawodawstwem, ideologiczne podłoże dyskusji w tej mierze, pod wspólnym hasłem „mieszania się kościoła do polityki” czy też granic tego „mieszania się”, do wyznaczania których nie brakuje chętnych, wykazuje, że najczęściej nie mamy do czynienia z ignorancją dyskutantów, lecz z atakiem na Kościół i wolność religijną.

Wystarczy i należy sięgnąc do realistycznych definicji ,prawa” i ,polityki”, aby nie popaść w prowadzące donikąd zrelatywizowane dyskursy. Już w świetle tak podstawowej definicji ,,prawa”, jako roztropnego rozrządzenia rozumu niezbędnego dla realizacji dobra wspólnego, gdzie adresatem jest dobro człowieka, czy też definicji ,polityki”, jako roztropnej

43 Uwaga dotyczy religii katolickiej.

44 Krukowski 2008, 68. Podobnie H. Misztal podkreślając, że normy prawa międzynarodowego posługują się w identycznym kontekście pojęciem „bezpieczeństwa publicznego”, Misztal, w: Mezglewski, Misztal, Stanisz 2011,72. 
troski o dobro wspólne, widać absurdalność tkwiącą w samych sformułowaniach typu „mieszanie się do polityki”, pojmowanych jako coś negatywnego. Może w tym miejscu zostać podniesiony zarzut, że nie o taką „politykę" tu chodzi, tylko o jeden z jej wymiarów (narzędzi), którym jest udział w sprawowaniu władzy państwowej lub sięgania po nią. Jednakże, przedmiotem publicznych dyskusji w naszym państwie raczej nie jest działalność duchownych - posłów, albo duchownych - ministrów, ale samo prawo zabierania głosu i zajmowania stanowisk w przedmiocie szeroko rozumianych spraw publicznych. Każda próba redukowania „wolności sumienia i wyznania”, czy „wolności religii”, do aspektu swoiście pojmowanej ,prywatności” wyrażanej np. w haśle: „miejsce Kościoła jest w zakrystii", jest nie tylko sprzeczna z obowiązującym porządkiem prawnym, ale przede wszystkim jest uderzeniem w podstawowe prawa człowieka, z racji na religijność jego natury. Naruszenie jednego z wyrażonych w Konstytucji praw człowieka (obywatela), jakim jest wolność religijna (sumienia, wyznania, religii), rozumiana dwuaspektowo - tzn. ,prywatnie” i ,publicznie" - jest jednocześnie naruszeniem pozostałych praw i podważeniem konstytucyjnych zasad o charakterze ustrojowym, od zasady demokratyczności państwa, czy też zasady państwa prawa zaczynając.

\subsection{UWAGI W ASPEKCIE PRAWA KOŚCIELNEGO}

W czasach przedsoborowych ${ }^{45}$ nierzadki był widok kapłana - senatora, czy osoby duchownej sprawującej tzw. polityczne urzędy. Sytuacja zmieniła się radykalnie wraz z przyjętymi przez Sobór Watykański II nowymi rozwiązaniami, które znalazły swój wyraz w normach Kodeksu Prawa Kanonicznego, posoborowych synodach biskupów oraz innych dokumentach Kościoła.

Obecnie, w przepisach Kodeksu Prawa Kanonicznego mamy do czynienia $\mathrm{z}$ wyrażonym expressis verbis bezwzględnym zakazem sprawowania przez duchownych publicznych urzędów, z którymi łączy się udział w wykonywaniu władzy świeckiej (kan. 285 §3 KPK), zakaz takiego uczestnictwa w stowarzyszeniach, który pozostaje w kolizji z obowiązkami duchownych (kan. $278 \S 3 \mathrm{KPK}$ ), czy też względny zakaz czynnego

45 Chodzi o Sobór Watykański II. 
udziału w partiach politycznych albo w kierowaniu związkami zawodowymi (kan. 287 §2 KPK).

Powyższe ograniczenia w sprawowaniu funkcji publicznych przez osoby duchowne są jednoznacznie sprecyzowane na gruncie Kodeksu Prawa Kanonicznego.

Zakaz z kan. 285 §3 KPK, wyraźnie dotyczy przyjmowania publicznych urzędów, ale tylko takich, z którymi łączy się udział w wykonywaniu władzy świeckiej. Chodzi tu o władzę świecką w najszerszym tego słowa znaczeniu, tzn. o władzę ustawodawczą, wykonawczą i sądowniczą, a nie o wąsko rozumianą władzę wykonawczą we współczesnym państwie ${ }^{46}$. Uwaga ta dotyczy wszystkich rodzajów i szczebli organów ,świeckich”, tzn. państwowych i samorządowych. Takie rozumienie jest powszechnie akceptowane w doktrynie prawa kanonicznego ${ }^{47}$.

Jak się podkreśla ${ }^{48}$, zakaz ten ma swoje uzasadnienie w ontologii kapłaństwa urzędowego, co uwydatnił Sobór stwierdzeniem, że duchowni „są wyświęcani, aby głosić Ewangelię, być pasterzami i sprawować kult Boży, jako prawdziwi kapłani Nowego Testamentu"49. Powołaniem Kościoła jest głoszenie prawdy o Bogu i Jego stworzeniu. Prawdy o zbawieniu. Toteż duchowni nie powinni stawać się stroną działań czy sporów politycznych, w wąskim znaczeniu ,ppolityki”. Zakaz z kan. 285 §3 jest bezwzględnie obowiązujący. Kodeks nie przewiduje od niego żadnych wyjątków, a za jego naruszenie przewiduje sankcje karne, przede wszystkim w oparciu o dyspozycję kan. 1399 KPK.

Źródła powyższego zakazu znajdujemy w dokumentach Soboru Watykańskiego II. I tak - Konstytucja duszpasterska o Kościele w świecie współczesnym Gaudium et spes ${ }^{50}$ przypomina, że: „Właściwe posłannictwo, jakie Chrystus powierzył swemu Kościołowi, nie ma charakteru politycznego, gospodarczego czy społecznego: cel bowiem, jaki Chrystus nakreślił Kościołowi, ma charakter religijny”. Konstytucja ta podkreśla

46 Rincón-Pérez 2011, 267.

47 Por. Krukowski 2005, 110.

48 Por. tamże, 109.

49 Konstytucja dogmatyczna o Kościele Lumen Gentium, 28.

50 Dokumenty nauki społecznej Kościoła. Część I, red. Marian Radwan, Leon Dyczewski, Adam Stanowski (Rzym-Lublin: Fundacja Jana Pawła II. Polski Instytut Kultury Chrześcijańskiej, 1987): 313-378. 
uniwersalność misji Kościoła, która jest skierowana do wszystkich ludzi. Naturalnie więc Kościół nie może utożsamiać się z konkretnym systemem politycznym, czy też politycznym zrzeszeniem. Jak czytamy: „Wspólnota polityczna i Kościół są, każde na własnym terenie, od siebie niezależne i autonomiczne".

Synod Biskupów z 1971 roku wskazuje, że działalność polityczna chodzi tu o działalność w wąskim tego słowa znaczeniu, a nie w klasycznym pojęciu polityki, jako roztropnej troski o dobro wspólne ${ }^{51}$ - jest dziedziną zarezerwowaną tylko dla świeckich. Stwierdzając, że ze względu na to, iż opcje polityczne jako takie mają ograniczony zakres i nie interpretują nigdy Ewangelii w formie całkowicie adekwatnej i trwałej, prezbiter jako świadek przyszłej rzeczywistości ,powinien zachować pewien dystans wobec jakiejkolwiek funkcji lub pasji politycznej”. A święty Jan Paweł II, zwracając się do księży i zakonników w Guadalupe w 1979 r., powiedział wprost, że „kapłani mają być przywódcami duchowymi, a nie przywódcami politycznymi”, czy też innymi funkcjonariuszami władzy świeckiej ${ }^{52}$.

Zgodnie z dyspozycją kan. 287 §2 KPK, duchowni nie mogą brać czynnego udziału w partiach politycznych ani w kierowaniu związkami zawodowym. Zakaz ten jest jednak względny, w przeciwieństwie do wyżej poruszonego. Omawiany przepis stanowi bowiem, że duchowni nie podlegają temu ograniczeniu jeśli zdaniem kompetentnej władzy kościelnej, podjęcie wymienionych zaangażowań jest konieczne dla obrony praw Kościoła lub rozwoju dobra wspólnego. Zgodnie ze stanowiskiem Synodu Biskupów w 1971 r., „Przewodniczenie partiom politycznym lub udział w walce w imieniu jakiejkolwiek partii politycznej jest zabronione jakiemukolwiek kapłanowi”. Ratio legis zakazu z kan. 287 §2 KPK, leży w szczególności w dyspozycji §1 tego kanonu, który werbalizuje obowiązek duchownych działania na rzecz zachowania między ludźmi pokoju i zgody, opartej na sprawiedliwości. Zadaniem duchownych jest zatem budowanie jedności, jako elementu dobra wspólnego. Natomiast zaangażowanie w bieżącą walkę polityczną może być budowaniem konfliktu i w rezultacie zagrażać dobru wspólnemu, co nie jest roztropne nawet

51 Uwaga moja.

52 Artur Stopka, „Księża i polityka - co wolno, a czego nie?” Aleteia, 13 czerwca 2017 r., https://pl.aleteia.org/2017/06/13/ksieza-i-polityka-co-wolno-a-czego-nie/ [dostęp: 1.08.2017]. 
w sytuacji doraźnego wsparcia strony politycznego sporu. Nie wspominając już o ewangelizacyjnej misji Kościoła.

Z brzmienia kan. 287 §2 KPK wynika, że zwolnienie z zakazu działalności partyjnej czy związkowej musi być konieczne, tzn. niezbędne ze względu na wyrażony w tym przepisie cel, którym jest obrona praw Kościoła, czy dobro wspólne. Wydaje się, że przedmiotem takiego zwolnienia mogą być raczej ściśle określone rodzajowo i czasowo indywidualne przypadki, a nie zwolnienie „w ogóle” na kształt carte blanche.

Pojęcie uprawnionego celu, którym jest dobro wspólne, jest bardzo szerokie. Teoretycznie z aktualnością takiego celu mamy do czynienia stale. Toteż wydaje się, że chodzi tutaj o sprawy mające szczególnie istotne znaczenie, określane mianem non possumus.

Zakaz zaangażowania w partie polityczne jest szerszy niż w odniesieniu do związków zawodowych. Czynny udział w partiach politycznych oznacza uczestnictwo w zakładaniu partii, każdy rodzaj członkostwa w partii, a tym bardziej obecność w jej władzach. Za taki udział może też być także uznana określona aktywność duchownego, nawet wtedy, gdy formalnie nie jest członkiem partii politycznej.

Z kolei zakaz dotyczący działalności związkowej jest literalnie węższy, gdyż dotyczy wyłącznie kierowania związkami zawodowymi. Należy jednak mieć na uwadze ograniczenia stowarzyszania się zawarte w kan. 278 §3 KPK oraz związany z tymi ograniczeniami zakaz tzw. duchownych związków zawodowych, zawarty w Deklaracji Kongregacji ds. Duchowieństwa z dnia 8 marca 1982 r. Dokument ten wymienia, jako przykład niedopuszczalnych stowarzyszeń takie, które „usiłują zrzeszać duchownych w swego rodzaju «związki zawodowe» traktując posługę kapłańską jako zwykły stosunek pracy, pasterzy Kościoła zaś, jako pracodawców"53.

Kolejne ograniczenia publicznych zaangażowań osób duchownych zawarte są w kan. 278 KPK. Przepis $§ 1$ tego kanonu wyraża - co jest posoborową nowością - prawo duchownych diecezjalnych do zrzeszania się. Jednocześnie prawo to jest - expressis verbis - ograniczone do takiego typu i sposobu zrzeszania się, które służą osiąganiu celów zgodnych ze stanem duchownym ( $278 \S 3 \mathrm{KPK})$. Nawet bez tego ostatniego zastrzeżenia

53 Św. Kongregacja Ds. Duchowieństwa, Dekret Quidam Episcopi z 8 marca 1982 r., AAS 74(1982), s. 642-645, cyt. za: Krukowski 2005, 100-101. 
prawodawcy, powyższe ograniczenie byłoby wyprowadzane z ogólnych obowiązków przynależnych stanowi duchownemu. Ważną w niniejszych rozważaniach jest dyspozycja przepisu $\S 3 \mathrm{w}$ tym kanonie. Stanowi ona zakaz zakładania lub przynależności duchownych do takich stowarzyszeń, których cel albo działalność nie dadzą się pogodzić z obowiązkami właściwymi stanowi duchownemu lub mogłyby przeszkadzać w sumiennym wypełnianiu zadania zleconego im przez kompetentną władzę kościelną. Również to ograniczenie można niezależnie wyprowadzić z ogólnych obowiązków duchownych, w tym z norm dyscyplinarnych właściwych stanowi kapłańskiemu (kan. 259-262 KPK).

Prawo kapłanów do zrzeszania się, wyrażone w $§ 1$ kanonu 278, nie jest tylko uprawnieniem, ale jest rzeczywistym ius, uznanym i sformalizowanym przez prawo pozytywne Kościoła. Przy jednoczesnym zachowaniu prawa i obowiązku hierarchii do sprawowania nadzoru nad stowarzyszeniami, co wyraża się w szczególności w wymogu zatwierdzania stowarzyszeń albo udzielenia im nihil obstat ${ }^{54}$.

Dokumenty Kościoła odnoszą się do tego prawa oraz dotyczących go ograniczeń. W szczególności, Kongregacja ds. Duchowieństwa w wydanej przez siebie deklaracji z 8 marca 1982 roku odnosi się do stowarzyszeń, czy raczej do zrzeszeń ${ }^{55}$, które mają polityczny lub związkowy charakter. Wskazuje na to język deklaracji, która zawiera zakaz uczestnictwa w stowarzyszeniach, mających cele niezgodne ze stanem duchownym, jak np. partie polityczne, czy związki zawodowe. W uzpełnieniu takiego zakazu deklaracja zabrania m.in., uczestnictwa duchownych w takich stowarzyszeniach, które bezpośrednio lub pośrednio, w sposób oczywisty lub ukryty, służą osiąganiu celów politycznych. Ponadto, deklaracja zawiera, powołany wyżej zakaz związków zawodowych duchownych ${ }^{56}$. Widoczna jest dbałość o to, aby owo ius do zrzeszania się, nie służyło omijaniu pozostałych, przywołanych wyżej bezwzględnych lub względnych ograniczeń publicznych zaangażowań osób duchownych.

Przywołane wyżej ograniczenia zawarte w KPK nie oznaczają oczywiście, że duchowni nie mogą mieć swoich poglądów politycznych i tracą

\footnotetext{
54 Rincón-Pérez 2011, 261.

55 Pojęcie szersze w państwowej doktrynie i legislacji - uwaga autora.

56 Krukowski 2005, 100-101.
} 
wszelkie prawa obywatelskie w tzw. ,politycznej” materii. Mamy tutaj do czynienia wyłącznie z ograniczeniami tych praw $^{57}$ o wyjątkowym charakterze. Przykładowo, ograniczenia z zakresu biernego prawa wyborczego, nie oznaczają ograniczeń praw wyborczych „w ogóle”.

W liście do kapłanów na Wielki Czwartek w 2017 roku, polscy biskupi stwierdzili, że „każdy ksiądz jako obywatel naszego kraju ma prawo do swoich poglądów politycznych, udziału w wyborach oraz zabierania głosu w debacie publicznej, zwłaszcza w kwestiach moralnych”, jednakże „każda publiczna aktywność księdza wymaga roztropnego odróżnienia polityki jako troski o dobro wspólne od zaangażowania w konkretne polityczne projekty. Rezygnujemy z tej ostatniej aktywności w imię pierwszeństwa naszej kościelnej misji. Bezpośredni udział w bieżącej polityce pozostaje domeną katolików świeckich". Zauważając zarazem, że w konkretnych sytuacjach rozróżnienie wąsko rozumianego „,politykowania” od roztropnej troski o dobro wspólne bywa trudne, zwłaszcza w sytuacji ostrych sporów politycznych, należy jednak pamiętać, że ,posłannictwo księdza jest uniwersalne, czyli skierowane do każdej strony politycznego sporu. Dla nas każdy człowiek jest przede wszystkim umiłowanym dzieckiem Boga"58.

Szczególne zasady dotyczące wypowiedzi osób duchownych w przestrzeni publicznej znajdują się w dokumencie Konferencji Episkopatu Polski ogłoszonym dnia 9 marca 2005 roku, pt. Normy Konferencji Episkopatu Polski dotyczace występowania duchownych i osób zakonnych oraz przekazywania nauki chrześcijańskiej $w$ audycjach radiowych i telewizyj$n y c h^{59}$. W dokumencie tym, zwanym dalej Normami KEP, zawarte są po-

57 Rozumianych także jako prawa obywatelskie.

58 Cyt. za: Artur Stopka, „Księża i polityka - co wolno, a czego nie?” Aleteia, 13 czerwca 2017 r., https://pl.aleteia.org/2017/06/13/ksieza-i-polityka-co-wolno-a-czego-nie/ [dostęp: 1.08.2017].

59 „Konferencja Episkopatu Polski biorąc pod uwagę Instrukcję Kongregacji Nauki Wiary o pewnych aspektach używania społecznych środków przekazu dla szerzenia nauki o wierze z 30 marca 1992 r. i korzystając z uprawnień przyznanych przez prawo powszechne (kan. $772 \S 2$; kan. $804 \S 1$; kan. $831 \S 2$ ), podczas 328. zebrania plenarnego, które odbyło się w Licheniu w dniach 11-12 czerwca 2004 r., przyjęła następujące zasady regulujące duszpasterską troskę Kościoła w Polsce o uporządkowany przekaz ewangelicznego orędzia poprzez radio i telewizję". Cyt. za: http://episkopat.pl/normy-konferencji-episkopatu-polski-dotyczace-wystepowania-duchownych-i-osob-zakonnych-oraz-przekazywania-nauki-chrzescijanskiej-w-audycjach-radiowych-i-telewizyjnych/ [dostęp: 1.08.2017]. 
stanowienia, które reglamentują zarówno zasady udziału, jak i wypowiedzi duchownych w mediach. Z punktu widzenia prawa państwowego, mamy tu do czynienia z wewnętrznymi regulacjami Kościoła o samoograniczającym $^{60}$ charakterze. Już na wstępie Normy KEP przywołują prawo i obowiązek Kościoła - wynikający z misji głoszenia Ewangelii - do posługiwania się mediami. Działalność duchownych, będąca przedmiotem Norm KEP, podlega nadzorowi właściwych biskupów diecezjalnych, a w przypadkach o ogólnopolskim charakterze, także nadzorowi Konferencji Episkopatu Polski. Nadzór ten oznacza m.in. wymóg uzyskania zgody właściwych władz kościelnych (pkt 1, 23, 4, 6, 14, 16, 21 Norm KEP). Omawiany dokument podkreśla, że medialne aktywności „opierają się na autorytecie Kościoła i są odbierane jako jego głos” (pkt 2 Norm KEP).

Należy w szczególności przywołać takie zasady dotyczące medialnych wypowiedzi zawarte w Normach KEP, jak: 1) spoczywający na duchownych obowiązek wierności nauce Ewangelii (pkt 3, 19); 2) obowiązek wypowiadania się wyłącznie w granicach własnej kompetencji duchownego, co ma znaczenie zwłaszcza w odniesieniu do audycji ,trudnych i kontrowersyjnych" (pkt 8); 3) obowiązek wiernego przekazu doktryny Kościoła oraz respektowania oficjalnych stanowisk Konferencji Episkopatu Polski, przy odpowiedniej rezygnacji z rozpowszechniania przez duchownych „opinii własnych” (pkt 9); 4) zakaz wypowiadania się w imieniu Kościoła oraz sugerowania, że jest się jego rzecznikiem, bez stosownego upoważnienia (pkt 11); 5) nakaz powstrzymania się przez wiernych świeckich, dotyczący także duchownych, od ,udziału w programach czy audycjach przynoszących szkodę wierze lub dobrym obyczajom, tendencyjnie antykościelnych i budzących zgorszenie" (pkt 12); 6) wymóg uzyskania przez osobę duchowną zgody właściwego ordynariusza na stałą współpracę ze stacją radiową lub telewizyjną (pkt 13); 6) obowiązek występowania w telewizji w stroju duchownym używanym w Polsce (pkt. 15).

Zgodnie z pkt. 21 Norm KEP, w razie ,,poważnego naruszenia powyższych norm ordynariusz winien upomnieć duchownego lub członka instytutu zakonnego i zobowiązać go do naprawienia szkody, np. poprzez sprostowanie lub odwołanie błędnej czy krzywdzącej wypowiedzi. W uzasadnionych i poszczególnych przypadkach ordynariusz może zabronić wy-

${ }^{60}$ W relacji do prawa państwowego. 
powiadania się w mediach lub zastosować inne sankcje przewidziane przez prawo kościelne.

\section{WNIOSKI}

Obowiązująca reglamentacja prawna z zakresu polskiego prawa państwowego oraz prawa międzynarodowego nie zawiera żadnych podstaw do różnicowania statusu prawnego osoby duchownej i nie będącego taką osobą obywatela w zakresie działalności publicznej. Niezależnie od przyjętej definicji tej działalności, tzn. węższej odwołującej się do osoby ,publicznej”, „funkcjonariusza publicznego”, „spraw publicznych”, itd. w rozumieniu prawa państwowego, czy też rozszerzającej znaczenie wyrażenia „publiczne” na sprawy nieprywatne o powszechnym, w szczególności o społecznym lub politycznym charakterze.

Istotą kontestacji udziału osób duchownych w życiu publicznym, która ma miejsce w odwołaniu do powyższego porządku prawnego, jest bezpodstawne założenie o rzekomej ,inności” duchownych od innych obywateli państwa w zakresie przysługujących im praw obywatelskich. Takie odmienne traktowanie pozycji prawnej duchownego jest sprzeczne z normami prawa międzynarodowego wiążącymi Polskę oraz z polskim prawodawstwem wewnętrznym. Równość obywateli wobec prawa, niezależnie od bycia duchownym, wyraźnie stwierdza międzynarodowy i polski prawodawca.

Omówione wyżej ograniczenia w sprawowaniu funkcji publicznych oraz w prowadzeniu działalności o publicznym ${ }^{61}$ charakterze przez osoby duchowne, są natomiast jednoznacznie sprecyzowane na gruncie Kodeksu Prawa Kanonicznego oraz przywołanych, pozostałych norm prawa kościelnego. Ograniczeń takich nie można wyprowadzić pozostając wyłącznie na gruncie prawa państwowego.

Pomimo jednoznaczności postanowień KPK, są one wykorzystywane w dyskusji publicznej w szerszym ich znaczeniu. Wraz z błędnym rozumieniem ,,autonomii Kościoła i państwa”, ,polityki”, , prawa” czy konstytucyjnych wolności, w tym religijnej, próbuje się wymienione ograniczenia

${ }^{61}$ Także w znaczeniu ,upowszechnienienia”. 
interpretować, jako dotyczące każdego działania w sferze publicznej, pojmowanej jako „nieprywatnej”, tzn. takiej, która dotyka spraw publicznych, rozumianych, jako ,polityczne” lub ,społeczne”. W tym momencie pojawiają się nieuprawnione oskarżenia o tzw. ,mieszanie się Kościoła do polityki". Tak rozszerzające podejście, nie znajduje żadnego usprawiedliwienia, jako sprzeczne nie tylko z normami prawa kanonicznego, ale także prawa państwowego i międzynarodowego. Owo rzekome naruszenie autonomii Kościoła i państwa ma polegać na „nieuprawnionej” ingerencji duchownych w zadania państwa („Kościół miesza się do polityki”). Znamienne jest to, że wskazany zarzut nie jest podnoszony na gruncie prawa kanonicznego, ale na płaszczyźnie państwowego porządku prawnego. A przecież osoba duchowna, jest w tym ostatnim porządku obywatelem, któremu przysługują takie same konstytucyjne prawa, jak każdemu innemu.

Należy podkreślić, że ograniczenia ${ }^{62}$ dotyczące działalności o charakterze publicznym, w tym sprawowania funkcji publicznych przez osoby duchowne, mają swoje źródło i oparcie w wewnętrznym prawie kościelnym, a nie państwowym. To właśnie z dobrej woli Kościoła i z jego troski o dobro wspólne, właściwe sprawowanie funkcji duchownej oraz poszanowanie autonomii Kościoła i państwa, wynikają przywołane w tej wypowiedzi ograniczenia. Toteż, jedynie uprawnionym stanowiskiem jest to, że wszelkie ograniczenia ${ }^{63}$ zaangażowań duchownych w działalność publiczną można rozpatrywać wyłącznie na gruncie prawa kanonicznego. Dotyczy to szeroko pojętej działalności o ,publicznym”, tzn. powszechnym charakterze, jak i publicznej w rozumieniu prawa państwowego, w tym sprawowania funkcji publicznych. Stanowisko takie wynika z obowiązującego porządku prawnego, w tym z konstytucyjnej zasady autonomii Kościoła i państwa.

Dla zasadności powyższego stanowiska nie ma znaczenia zredukowanie dyskusji ${ }^{64}$ do płaszczyzny pozytywistyczno-prawnej. Już przy pobieżnym odniesieniu się do wymienionej wyżej, rozszerzającej interpretacji ograniczeń dotyczących zaangażowań duchownych, ujawnia się jej absurdalność. Osoba duchowna jest z samej istoty swego stanu taką, której działalność wkracza w sferę ,publiczną”. I to zarówno w szerokim znaczeniu „niepry-

\footnotetext{
${ }^{62}$ W stosunku do ,nie-duchownych”.

63 Jak w przyp. powyżej.

${ }^{64} \mathrm{~W}$ przedmiocie niniejszych rozważań.
} 
watności”, jak i w wąskim znaczeniu „spraw publicznych”, których dotyczy obowiązująca reglamentacja prawa państwowego. Ewangelizacyjna misja Kościoła wykracza poza ,zakrystię”, czy prywatność osób duchownych. Pan Jezus został ukrzyżowany za działalność publiczną, a mówiąc współczesnym językiem, wydany na Niego wyrok oparty był m.in. na zarzucie nieuprawnionego - zdaniem sądzących - „mieszania się do polityki”.

Niniejszy artykuł, z racji na ograniczoność jego ram, w niewielkim stopniu wyczerpuje rozpatrywaną problematykę. Wieloaspektowość samego zagadnienia oraz wywołanie w tej pracy wybranych kwestii, może będzie skromnym przyczynkiem do dalszej dyskusji.

\section{BIBLIOGRAFIA}

Abramowicz, Aneta. 2007. „Przedmiotowy zakres wolności religijnej”. Studia z Prawa Wyznaniowego 10: 325-352.

Bielecki, Marek. 2014a. „Uzewnętrznianie przekonań religijnych”. W: Leksykon prawa wyznaniowego 100 podstawowych pojęć, red. Artur Mezglewski, 490497. Warszawa: C.H. Beck.

Bielecki, Marek. 2014b. „Wolność religijna”. W: Leksykon prawa wyznaniowego 100 podstawowych pojęć, red. Artur Mezglewski, 513-520. Warszawa: C.H. Beck.

Dudziak, Jan. 2002. Gwarancje wolności religijnej w Konkordacie zawartym między Stolica Apostolska a Rzeczypospolita Polska w 1993. Tarnów: Biblos.

Krukowski, Józef. 2003. „Religia i wolność religijna w prawie Unii Europejskiej. Doświadczenia i perspektywy”. W: Kultura i prawo. Materiały III Międzynarodowej Konferencji na temat ,Religia i wolność religijna w Unii Europejskiej”, Warszawa, 2-4 września 2002, red. Józef Krukowski, Otto Theisen, 217-230. Lublin: Towarzystwo Naukowe KUL.

Krukowski, Józef (red.). 2005. Komentarz do kodeksu prawa kanoniczego, tom II/I. Poznań: Pallotinum.

Krukowski, Józef. 2008. Polskie prawo wyznaniowe. Warszawa: Lexis Nexis.

Mezglewski, Artur. 2001. „Pojęcie «duchownego» w przepisach prawa polskiego o zawieraniu małżeństw”. Studia Prawa Wyznaniowego 2: 3-26

Mezglewski, Artur. 2005. „Nieścisłości terminologiczne w przepisach prawa polskiego a zawieranie małżeństw wyznaniowych ze skutkami cywilnymi i ich praktyczne konsekwencje". Ius Matrimonaile 10: 193-206. 
Mezglewski, Artur, Henryk Misztal, Piotr Stanisz. 2011. Prawo wyznaniowe. Warszawa: C.H. Beck.

Misztal, Henryk. 1993. „Kościelne pojęcie wolności religijnej, a ustawa o gwarancjach wolności sumienia i wyznania". Kościót i Prawo 11: 103-122.

Orzeszyna, Krzysztof. 2002. „Karta Praw Podstawowych Unii Europejskiej a wartości religijne”. Prawo - Administracja - Kościót 2-3(10-11): 175-195.

Rincón-Pérez, Tomás. 2011. W: Kodeks Prawa Kanonicznego. Komentarz, red. Piotr Majer. Kraków: Wolters Kluwer.

Tunia, Anna. 2014. „Duchowny”. w: Leksykon prawa wyznaniowego 100 podstawowych pojęć, red. Artur Mezglewski, 62-69. Warszawa: C.H. Beck.

Warchałowski, Krzysztof. 2004. „Ochrona prawa do wolności religijnej w prawie traktatowym Unii Europejskiej. Studia z Prawa Wyznaniowego 7: 5-18.

\section{LEGAL ASPECTS OF THE PUBLIC ACTIVITY OF CLERGYMEN}

\section{Summary}

In the Polish legal system the term "clergyman" is determined on the basis of the internal regulations of churches and other religious organizations. Clergymen, as Polish citizens, have the same rights as all other citizens. Limitation of the rights of the clergy as regards their public activity would be a violation of constitutional provisions, regulations of ratified international agreements and statutory provisions.

In accordance with the Code of Canon Law (CIC), the clergy are strictly prohibited from holding public offices connected with exercising secular power (CIC, c. $285 \S 3$ ), from such participation in associations which collides with the duties of the clergy (CIC, c. $278 \S 3$ ). In addition, there is a relative prohibition to actively participate in political parties or in the management of trade unions (CIC, c. 287 $\S 2$ CIC). Any restrictions on the public activity of the clergy can be considered only under canon law. This is due to the existing legal order, including the constitutional principle of the autonomy of Church and State.

Key words: clergy; churches and other religious organizations; religious freedom; Catholic Church; autonomy of Church and State; public functions; constitutional rights 